\title{
Karakteristik Morfologi Lamun Thalassodendronciliatum (Forsskall) Hartog 1970 (Kelas: Magnoliopsida, Famili : Cymodoceaceae) Berdasarkan Tipe Substrat di Perairan Pantai Timur Kabupaten Bulukumba
}

\author{
Chair Rani*, Muhammad Basri,Devi Yulianti Bahar dan Meggy Yolanda
}

Program Studi IImu Kelautan, Fakultas IImu Kelautan dan Perikanan, Universitas Hasanudin Jl.Perintis Kemerdekaan Km. 10 Tamalanrea,Makassar, Sulawesi Selatan90245

Email:erickch_rani@yahoo.com

\begin{abstract}
Morphological characteristics of Thalassodendron ciliatum (Forsskall) Hartog 1970, (Class:Magnoliopsida, Family:Cymodoceaceae) Based on Substrat In Pantai Timur Water, Bulukumba
\end{abstract}

This study aims to determine the seagrass morphological characteristic based on substrates and analyze the relationship of environmental factors with the morphology of Thalassodendron ciliatum. A sampling at each station was done purposively according to the substrate. Sampling was carried out in 3 areas as replication by digging and taking seagrass complete with rhizome and its roots as many as 25 stands. Then the seagrass was cleaned from the sand and put into a sample bag and stored in a cooler. At the same time, sand and water samples were also taken to measure the nitrate and phosphate. The measured water quality in situ includes current speed, temperature, salinity, depth, and wave height. In the laboratory, measurements of morphological parameters of seagrass were done on the leaves, stems, rhizomes, and roots. The results showed that the sandy substrate (Kasuso Station: more protected) showed a longer and thicker leaf character, and a longer root with a greater number of roots, but had a number of leaves, rhizoma length, internode distance, and root diameter smaller than the area with the substrate was dominated by coral fragments (Panrangluhu Station). Under weak current conditions with high nitrate and phosphate content, they were characterized by the larger stem and leaf lengths with a large number of roots. Whereas in strong currents, seagrass was characterized by a greater number and area of leaves and root diameter. Areas with high waves, characterized by seagrasses that have larger stem diameters, longer rhizomes with larger diameters, and also longer internode distances

Keywords:morphometrics; seagrass; Thalassodendron ciliatum; substrate; Bulukumba

\section{Abstrak}

Penelitian ini bertujuan untuk mendeterminasi karakter morfologi lamun berdasarkan tipe substrat dan menganalisis keterkaitan faktor lingkungan dengan morfologi lamun Thalassodendron ciliatum. Sampling pada setiap stasiun dilakukan secara purposif dengan memperhatikan susbstrat dasar. Sampling dilakukan pada 3 area sebagai ulangan dengan cara menggali dan mengambil lamun lengkap dengan rhizoma dan akarnya sebanyak 25 tegakan. Kemudian lamun dibersihkan dari pasir dan dimasukkan ke dalam kantong sampel yang berisi air laut dan disimpan dalam kotak pendingin. Bersamaan dengan itu, juga diambil sampel pasir dan air untuk diukur kandungan nitrat dan fosfatnya. Kualitas air yang diukur secara insitu meliputi kecepatan arus, suhu, salinitas, kedalaman, dan tinggi gelombang. Di laboratorium diukur parameter morfologi lamun pada bagian daun, batang, rhizoma, dan akar. Hasil analisis menunjukkan bahwa pada substrat berpasir (Stasiun Kasuso:lebih terlindung) memperlihatkan karakter daun yang lebih panjang dan tebal, serta akar yang lebih panjang dengan jumlah akar yang lebih banyak, namun memiliki 
jumlah daun, panjang rhizoma, jarak internode, dan diameter akar yang lebih kecil dibandingkan dengan daerah yang substratnya didominasi oleh pecahan karang (Stasiun Panrangluhu). Pada kondisi arus yang lemah dengan kandungan nitrat dan fosfat yang tinggi, dicirikan oleh panjang batang dan daun yang lebih besar dengan jumlah akar yang banyak. Sedangkan pada arus yang kuat, lamun dicirikan oleh jumlah dan luasan daun serta diameter akar yang lebih besar. Daerah dengan gelombang yang tinggi, dicirikan oleh lamun yang memiliki diameter batang yang lebih besar, rhizoma yang lebih panjang dengan diameter yang besar, dan jarak internode yang juga lebih panjang.

KataKunci:morfometrik; lamun;Thalassodendron ciliatum;substrat; Bulukumba

\section{PENDAHULUAN}

Lamun (seagrass) adalah tumbuhan air berbunga (Anthophyta) yang hidup dan tumbuh terbenam di lingkungan laut, berpembuluh, berimpang (rhizoma), berakar, dan berkembang biak secara generatif (biji) dan vegetatif (Wagey, 2013). Lamun juga merupakan satu-satunya kelompok tumbuhan yang hidup di perairan laut dangkal dan tumbuh padat membentuk padang lamun dengan kepadatan mencapai 4.000 tegakan $/ \mathrm{m}^{2}$ dan mempunyai biomassa sebesar $2 \mathrm{~kg} / \mathrm{m}^{2}$. Padang lamun dapat membentuk vegetasi tunggal, tersusun atas satu jenis lamun yang tumbuh membentuk padang lebat, sedangkan vegetasi campuran terdiri dari 212 jenis lamun yang tumbuh bersama-sama pada satu substrat. Spesies lamun yang biasanya tumbuh dengan vegetasi campuran adalah Cymodocea rotundata, Halodule pinifolia, dan Syringodium isoetifolium. Sedangkan yang tumbuh dengan vegetasi tunggal adalah Thalassia hemprichii, Enhalus acoroides, Halophila ovalis, Halodule uninervis, Cymodocea serrulata, dan Thalassodendrom ciliatum (Sakey et al., 2015).

$\begin{array}{rcr}\text { Beberapa } & \text { hasil } & \begin{array}{r}\text { penelitian } \\ \text { marakteristik }\end{array}\end{array}$
lingkungan dapat memengaruhi morfometrik lamun (Caboco et al., 2009; Amale et al., 2016; Putri et al., 2018). Menurut Supriharyono (2007), tingginya unsur hara dalam substrat menggambarkan kondisi perairan yang subur, sehingga akar lamun menjadi lebih pendek karena tidak melakukan usaha lebih terhadap akarnya dalam mendapatkan nutrisi. Ketika kondisi unsur hara dalam substrat lebih tinggi dibandingkan dengan kolom perairan, maka lamun akan mengambil unsur hara melalui akar. Substrat memiliki peranan penting bagi pertumbuhan lamun, sebagai media tumbuh agar tidak terbawa arus dan gelombang serta sebagai sumber unsur hara. Lamun dapat tumbuh pada berbagai jenis karakteristik substrat, seperti substrat berlumpur, berpasir hingga pecahan karang (Yunitha et al., 2014)

Keberadaan substrat sangat penting bagi lamun, sebagai pemasok nutrisi dantempat hidup. Substrat yang menjadi tempat hidup lamun adalah lumpur, pasir, karang mati (rubble), campuran dari dua jenis substrat tersebut atau campuran ketiganya (Kiswara, 2000). Laju pertumbuhan lamun berbeda-beda dari lokasi yang satu dengan yang lainnya, karena kecepatan atau laju pertumbuhan lamun dipengaruhi oleh beberapa faktor antara lain tingkat kesuburan substrat, ukuran butiran, dan atau kandungan hara di kolom air (De Silva \& Amarasinghe, 2007; Yunitha, 2014; Amale et al., 2016; Sahertian \& Wakano, 2017).

Thalassodendron ciliatum merupakan salah satu jenis lamun yang dominan namun memiliki sebaran yang terbatas. Menurut Sjafrie et al. (2018), dari 366 lokasi penelitian di Indonesia, jenis T. ciliatum hanya ditemukan pada 33 lokasi atau hanya sekitar 9\%. Di Sulawesi Selatan hingga saat ini hanya ditemukan di sekitar Laut Flores saja, yaitu di kabupaten Selayar dan Bulukumba (Verheij, 1993; Kiswara, 1996). Lamun tersebut biasanya ditemukan tumbuh membentuk komunitas monospesifik yang dominan pada substrat pasir, rubble (pecahan karang mati), dan substrat keras (Priosambodo, 2007). Beberapa hasil penelitian memperlihatkan bahwa karakteristik lingkungan, termasuk substrat dapat mempengaruhi morfometrik lamun. Informasi dasar mengenai karakter 
morfometrik dari jenis lamun ini, kaitannya dengan substrat dasar perairan belum tersedia dalam literatur. Hal ini bisa dimaklumi karena sebarannya yang terbatas. Beberapa kajian mengenai jenis lamun $T$. ciliatum yang bisa diakses misalnya mengenai perkembangan serbuk sari dan penyerbukan dalam air (Ducker et al., 1978), ultrastruktur daun, serta komposisi dan struktur pembuluh pada daun (Barnabas \& Naido, 1980; Barnabas, 1982, Barnabas, 1983), struktur bunga (Kay, 2008), sistimatika dan aspek ekologinya (Duarte et al., 2012), epifit dan avertabrata yang berasosiasi (Browne et al., 2013), dan kemampuan dalam menyerap karbon (Mashorenget al., 2019a).

Hasil pengamatan pendahuluan jenis lamun T. ciliatum di perairan kabupaten Bulukumba, ditemukan di perairan Pantai Kasuso dan Pantai Panrangluhu. Kedua lokasi tersebut memiliki substrat yang berbeda, yaitu di Pantai Kasuso memiliki substrat pasir yang dominan dibanding pecahan karang dan sebaliknya di Pantai Panrangluhu yang lebih didominasi oleh pecahan karang. Perbedaan karakteristik substrat diduga berpengaruh terhadap morfometrik lamun sebagai respons terhadap perbedaan kondisi lingkungan (Amale et al., 2016). Berdasarkan hal tersebut, perlu dilakukan penelitian tentang analisis morfometrik lamun T. ciliatum berdasarkan tipe substrat di perairan Pantai Kasuso dan Pantai Panrangluhu, Kecamatan Bontobahari Kabupaten Bulukumba.

Penelitian ini bertujuan: (1) mengetahui perbedaan morfometrik lamun T. ciliatum berdasarkan tipe substrat dan (2) menganalisis keterkaitan faktor lingkungan dengan morfometrik lamun T. ciliatum di Perairan Pantai Kasuso dan Pantai Panrangluhu, Kabupaten Bulukumba.

\section{MATERI DAN METODE}

Penelitian dilaksanakan di Pantai Kasuso dan Panrangluhu, Kecamatan Bontobahari Kabupaten Bulukumba (Gambar 1). Analisis tekstur sedimen dilakukan di Laboratorium Oseanografi Fisika dan Geomorfologi Pantai Fakultas IImu Kelautan dan Perikanan, sedangkan pengukuran kadar nutrien sedimen dilakukan di Laboratorium Kimia dan Kesuburan Tanah Fakultas Pertanian, Universitas Hasanuddin.

Stasiun pengamatan ditentukan dengan menggunakan teknik purposive sampling, yaitu berdasarkan keterwakilan jenis substrat yang ditumbuhi lamun T.ciliatum. Lokasi penelitian dibagi kedalam 2 stasiun, yaitu Stasiun I berada di Pantai Kasuso yang mewakili lamun $T$. ciliatum yang tumbuh pada substrat pasir berkarang dan Stasiun II di Pantai Panrangluhu, mewakili lamunT.ciliatumyang tumbuh pada substrat rubble. Setiap stasiun dibagi menjadi 3 substasiun dan semua substasiun diambil titik koordinatnya dengan GPS.

Pengambilan sampel lamun dilakukan dengan menggali lamun menggunakan sekop sampai pada akarnya dan diusahakan akarnya tidak terputus. Lamun yang diambil sebanyak 25 tegakan setiap substasiun.

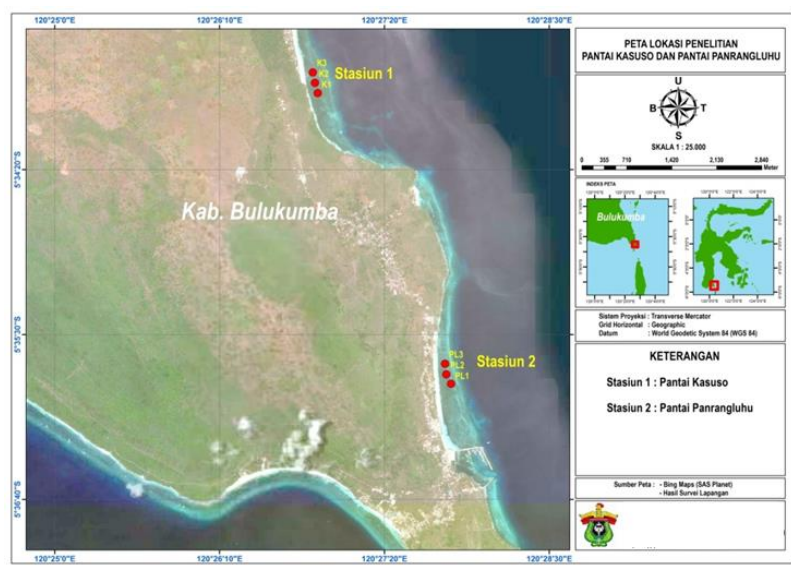

Gambar 1. Peta Lokasi Penelitian dan penempatan stasiun di Pantai Kasuso dan Pantai Panrangluhu, Kabupaten Bulukumba 
Kemudian lamun tersebut dibersihkan daripasir yang menempel. Setelah itu, sampel lamun dimasukkan ke dalam kantong sampel dan disimpan dalam coolbox yang berisi es (McDonalds et al., 2016).

Pengambilan sampel sedimen dasar perairan dilakukan pada setiap substasiun tempat mengambil sampel lamun sebanyak 3 kali ulangan. Sedimen diambil dengan menggunakan pipa PVC paralon berdiameter $9 \mathrm{~cm}$ dengan cara ditancapkan kedalam sedimen dan ditekan sampai kedalam $20 \mathrm{~cm}$. Kemudian sampel sedimen dimasukkan kedalam kantong sampel untuk dianalisis kandungan nitrat dan fosfat sedimen dengan spketrofotometer (APHA, 2017).

Parameter kualitas air yang diukur secara in situ, yaitu kecepatan arus dengan menggunakan layang-layang arus, suhu dengan termometer, salinitas dengan hand refractometer, kedalaman dengan tiang berskala, tinggi gelombang $(\mathrm{Hl} / 3)$ dengan tiang berskala. Semua parameter tersebut diukur secara in situ di setiap substasiun. Untuk kandungan nitrat dan fosfat perairan, diambil sampel air sebanyak $600 \mathrm{~mL}$ dan dimasukkan dalam coolbox untuk dianalisis di laboratorium. Prosedure pengukuran nitrat dan fosfat perairan mengikut metode Brucine dengan menggunakan spektrofotometer (APHA, 2017)

Pengukuran morfometrik lamun dilakukan dengan menggunakan caliper. Bagian lamun yang diukur seperti disajikan pada Gambar 2.Panjang dan lebar daun, panjang batang, panjang rhizoma, panjang internode, dan panjang akar diukur dengan menggunakan mistar dalam satuan $\mathrm{mm}$. Sedangkan diameter batang, rhizoma, dan akar serta tebal daun diukur dengan menggunakan caliper digital. Sedangkan luas lamun dihitung menurut Mashoreng et al. (2019b) dengan cara meletakkan daun lamun dari setiap tegakan pada kertas yang telah diberi garis batas (bingkai) dengan ukuran $15 \mathrm{~cm} \times 15 \mathrm{~cm}$, kemudian dipindai (discan). Garis batas dimasukkan agar luas bingkai dapat diketahui. Selanjutnya gambar hasil scan dianalisis menggunakan software Image-J untuk mendapatkan nilai persen tutupan daun lamun terhadap luas bingkai. Nilai persen tutupan daun lamun dikali dengan luas bingkai sehingga didapatkan luas daun lamun. Formula yang digunakan adalah :

$$
\mathrm{Ld}=\mathrm{Pd} \times \mathrm{Lb}
$$

Keterangan : $\mathrm{Ld}=\mathrm{Luas}$ daun $\left(\mathrm{cm}^{2}\right) \mathrm{Lb}=\mathrm{Luas}$ bingkai $\left(\mathrm{cm}^{2}\right) ; \mathrm{Pd}=$ Persentase tutupan daun lamunterhadap bingkai (\%)

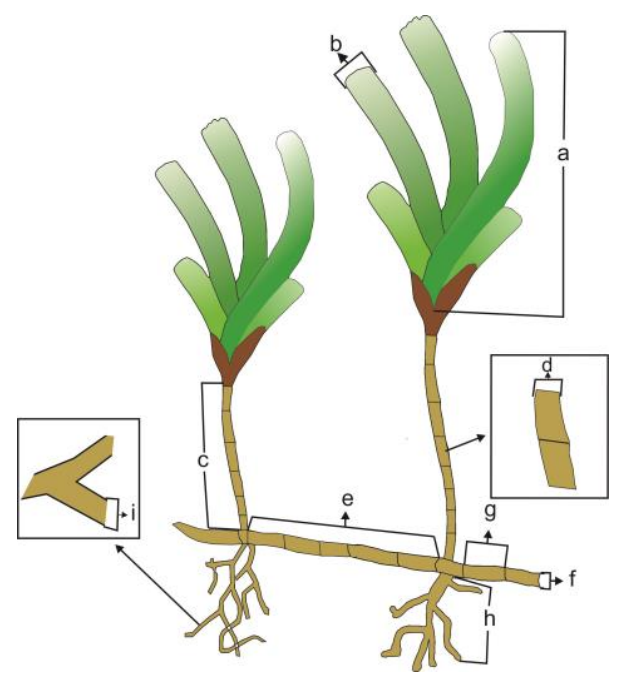

Gambar 2. Sketsa Pengukuran Morfometrik Lamun Thalassodendron ciliatum. a. panjang daun; b:lebar daun; c: panjang batang; d: diameter batang; e: panjang rhizoma; f: diameter rhizoma; g: panjang internode; h: panjang akar; i: diameter akar; j: jumlah daun; k: tebal daun; I: jumlah akar (Collier, 2013) 
Perbandingan setiap nilai variabel morfometrik antara tipe substrat dianalisis dengan uji t-student. Sedangkan keterkaitan antara ukuran faktor lingkungan dan butiran sedimen dengan karakter morfometrik lamun dianalisis dengan menggunakan analisis Principal Component Analysis (PCA). Proses perhitungan uji t-student dilakukan dengan bantuan perangkat lunak Microsoft Excel sedangkan analisis PCA digunakan program XL-Stat. Hasil analisis disajikan dalam bentuk tabel dan grafik.

\section{HASIL DAN PEMBAHASAN}

Hasil pengukuran rata-rata panjang daun, lebar daun, ketebalan daun, jumlah daun, dan luasan daun disajikan pada Gambar 3.Dari 5 variabel yang diukur di bagian daun, hanya 3 varibael yang menunjukkan perbedaan yang nyata $(p<0,05)$ antara stasiun penelitian. Rata-rata panjang daun T. ciliatum yang didapatkan di Stasiun Pantai Kasuso lebih tinggi $(70,5 \mathrm{~mm})$ dan berbeda nyata $(p<0,05)$ dibandingkan dengan Stasiun Panrangluhu (65,8 mm), demikian pula untuk ketebalan daun. Namun di sisi lain, jumlah daun nyata lebih banyak di Stasiun Panrangluhu dibandingkan Stasiun Pantai Kasuso. Parameter lebar dan luasan tidak memperlihatkan perbedaan yang nyata antara kedua stasiun (Gambar 3).
Lebih panjangnya daun T. ciliatum yang tumbuh di Stasiun Pantai Kasuso karena perbedaan substrat. Lamun pada Stasiun Pantai Kasuso tumbuh pada substrat pasir kasar yang memilliki kandungan nutrien lebih tinggi dibandingkan dengan lamun pada Stasiun Pantai Panrangluhu yang tumbuh pada substrat pasir yang sangat kasar (banyak pecahan karang). Selain itu, keadaan perairan pada Stasiun Pantai Kasuso yang lebih tenang sehingga banyak mengendapkan sedimen,khususnya sedimen organik yang dibutuhkan untuk pertumbuhan lamun. Pada perairan tenang pertumbuhan lamun lebih terpusat pada panjang dan lebar daun. Sedangkan ketebalan daun lamun T. ciliatum pada Stasiun Pantai Kasuso yang lebih tebal juga terkait dengan kondisi substrat. Lamun yang tumbuh pada substrat pasir sedang memiliki daun yang lebih tebal dibandingkan dengan lamun yang tumbuh pada substrat pasir kasar. Jika dibandingkan panjang daun di lokasi penelitian dengan rata-rata $6,58-7,05 \mathrm{~cm}$, lebih pendek dari yang dilaporkan oleh Pranata et al. (2018) di perairan Banggai Kepualauan, Sulawesi Tengah yang bisa mencapai $15 \mathrm{~cm}$. Banyak faktor lingkungan yang diduga berbeda di kedua lokasi kajian, seperti gerakan air (arus dan gelombang) dan perbedaan substrat dan kesuburannya.

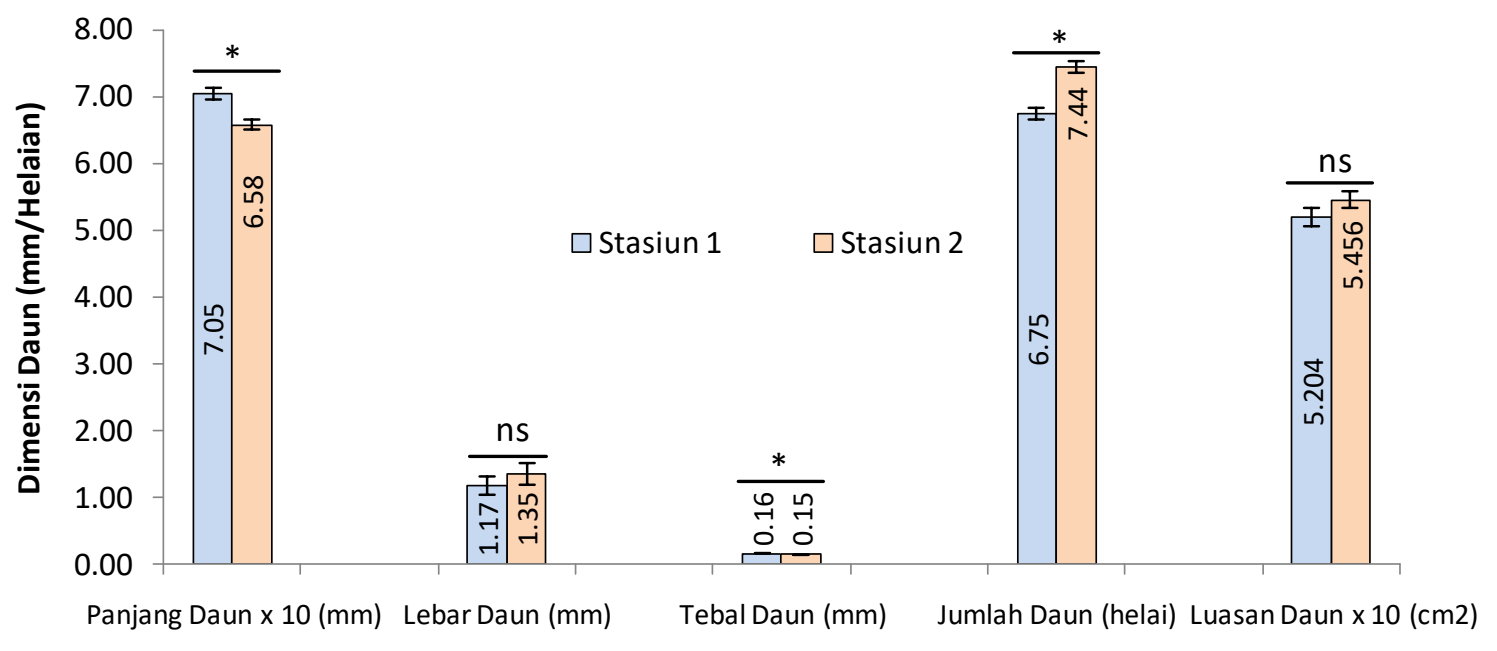

Bagian Daun

Gambar 3. Karakteristik pada daun lamun T. ciliatum pada kedua stasiun penelitian di Pantai Kasuso dan Pantai Panrangluhu, Kabupaten Bulukumba. (*: berbeda nyata pada alfa $5 \%$ berdasarkan uji t-student; ns: tidak berbeda nyata). 
Jumlah daun $T$. ciliatum yang tumbuh pada Stasiun Pantai Kasuso memiliki jumlah helaian daun yang lebih sedikit dibandingkan dengan lamun yang tumbuh Stasiun Pantai Panrangluhu. Laju pertumbuhan lamun berbeda-beda dari lokasi yang satu dengan yang lainnya, karena kecepatan atau laju pertumbuhan lamun dipengaruhi oleh beberapa faktor antara lain tingkat kesuburan substrat dan kandungan nutrien dalam perairan (Kiswara,1992). Ketika kondisi unsur hara pada kolom perairan lebih tinggi dibandingkan dengan kondisi dalam substrat, maka lamun akan mengambil unsur hara melalui daun (Supriharyono, 2007).

Meskipun panjang dan jumlah daun memperlihatkan perbedaan yang nyata namun, luasan daun tidak berbeda di kedua stasiun. Fenomena yang menarik bahwa jumlah daun di Stasiun Panrangluhu lebih banyak, namun panjang daunnya lebih pendek, sehingga luasan daun tidak berbeda di kedua stasiun tersebut.

Hasil pengukuran rata-rata panjang dan diameter batang dari lamun T. ciliatum di kedua stasiun penelitian disajikan Gambar 4.Panjang batang $T$. ciliatum yang didapatkan pada Stasiun 1 (Pantai Kasuso), yaitu 138,2 $\mathrm{mm}$ dan pada Stasiun 2 (Pantai Panrangluhu) sebesar $115,0 \mathrm{~mm}$. Hasil uji tstudent menunjukkan bahwa panjang batang lamun T.ciliatum pada Stasiun 1 lebih panjang dan berbeda nyata dengan Stasiun 2. Berdasarkan pengamatan secara visual, kondisi perairan pada Pantai Kasuso lebih keruh dibandingkan dengan Pantai Panrangluhu. Hal ini diduga menyebabkan kondisi perairannya lebih sedikit mendapatkan pencahayaan matahari, sehingga lamun mengupayakan dirinya dengan memanjangkan tangkai untuk mendapatkan cahaya matahari dalam melangsungkan proses fotosintesis. Pemanjangan morfologi lamun tersebut terjadi jika kondisi intensitas cahaya yang rendah (Abal et al., 1994).

Diameter batang $T$. ciliatum yang didapatkan pada kedua stasiun menunjukkan nilai yang tidak berbeda nyata dengan nilai masing-masing sebesar $2,35 \mathrm{~mm}$ di Pantai Kasuso dan $2,41 \mathrm{~mm}$ di Pantai Panrangluhu (Gambar 4). Ukuran diameter batang bisa mencerminkan pertumbuhan lamun. Lamun yang memiliki diameter batang yang lebar biasanya memiliki pertumbuhan yang lambat (Marba \& Duarte, 1998). Hasil pengukuran rata-rata rhizoma lamun T. ciliatum yang meliputi panjang, dan diameter rhizome, serta jumlah node dan jarak internode pada rhizoma di kedua stasiun penelitian, disajikan pada Gambar 5.

Panjang rhizoma T.ciliatum yang terukur di perairan Pantai Panrangluhu lebih panjang $(34,3 \mathrm{~mm})$ dan berbeda nyata dengan yang terukur di Pantai Kasuso $(29,8$ $\mathrm{mm})$. Lebih pendeknya rhizoma lamun di Pantai Kasuso masih terkait dengan kondisi substrat. Fenomena yang sama ditemukan oleh Wangkanusa et al. (2017), di Pantai

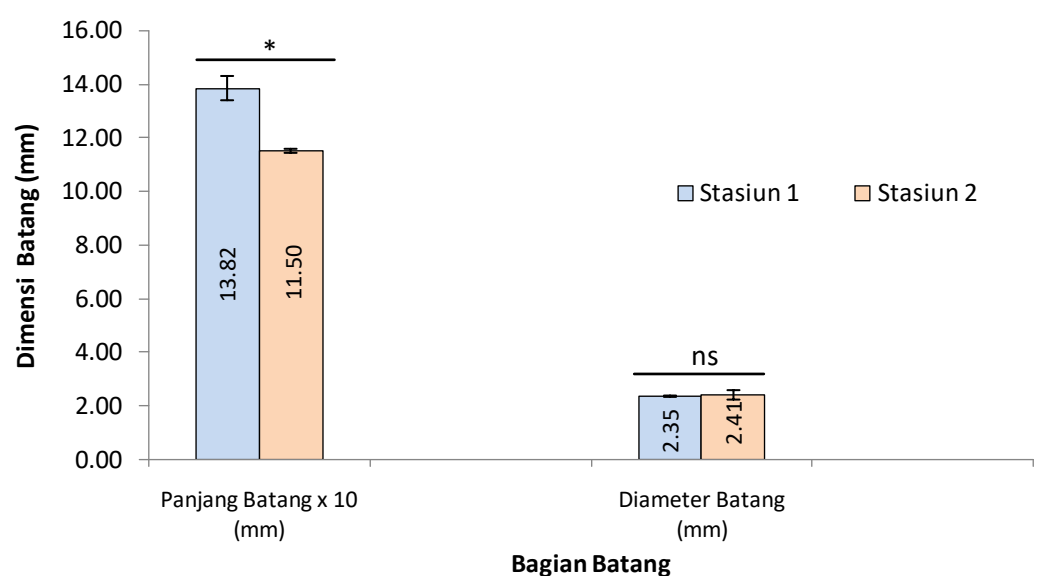

Gambar 4. Karakteristik pada batang lamun T. ciliatum pada kedua stasiun penelitian di Pantai Kasuso dan Pantai Panrangluhu, Kabupaten Bulukumba. (*: berbeda nyata pada alfa $5 \%$ berdasarkan uji t-student; ns: tidak berbeda nyata). 
Tongkeina, Kota Manado bahwa lamun yang hidup pada substrat berlumpur memiliki rhizoma yang lebih pendek dibandingkan dengan lamun yang hidup pada substrat pecahan karang. Lamun yang hidup pada substrat pecahan karang memiliki ukuran butir sedimen yang kasar dan tingkat porositas yang besar dan seragam. Kondisi substrat yang lebih berpori lebih labil dibanding substrat yang lebih halus. Olehnya itu agar lamun mampu bertahan maka mereka harus memperkuat sistem perakaran dan rhizomanya dengan tumbuh lebih panjang. Selain ketidakstabilan sedimen pada substrat yang lebih kasar, juga terkait dengan kandungan hara yang lebih rendah (porositasnya lebih besar: cepat terbilas). Menurut Supriharyono (2007), bahwa tingginya unsur hara dalam substrat menyebabkan akar lamun menjadi lebih pendek karena tidak melakukan usaha lebih terhadap akarnya dalam mendapatkan nutrisi.

Diameter rhizoma T. ciliatum yang terukur di Pantai Kasuso sebesar 4,39 mm dan di Pantai Panrangluhu sebesar $4,53 \mathrm{~mm}$ (Gambar 5). Hasil uji t-student menunjukkan bahwa kedua nilai tersebut tidak berbeda nyata $(p>0,05)$. Hasil ini juga seiring dengan hasil penelitian yang dilakukan Putri et al. (2018), substrat pasir dan bercampur dengan pecahan karang memiliki diameter rhizoma yang relatif lebih lebar dibandingkan dengan jenis substrat yang berkomposisi pasir.

Jumlah node $T$. ciliatum pada kedua lokasi penelitian masing-masing sebanyak 4 buah (Gambar 5) dan tidak menunjukkan perbedaan yang nyata, namun jarak internode memperlihatkan bahwa jarak internode lamun di Pantai Panrangluhu lebih panjang $(8,8 \mathrm{~mm})$ dan berbeda nyata dengan yang terukur di Panatai Kasuso (7,5 $\mathrm{mm})$. Berdasarkan hasil penelitian yang dilakukan pada kedua stasiun penelitian tersebut, jarak internode berbanding lurus dengan panjang rhizoma. Semakin panjang rhizoma maka jarak internode juga semakin panjang seperti yang terukur di Pantai Panrangluhu.

Hasil pengukuran rata-rata bagian akar lamun T. ciliatum yang meliputi panjang, dan diameter akar, serta jumlah akar di kedua stasiun penelitian disajikan pada Gambar 6 . Panjang akar $T$. ciliatum yang didapatkan pada kedua lokasi penelitian yaitu $82,1 \mathrm{~mm}$ di Pantai Kasuso dan $77,4 \mathrm{~mm}$ di Pantai Panrangluhu. Kedua nilai tersebut tidak berbeda nyata ( $p>005)$. Berdasarkan hasil penelitian yang dilakukan Wangkanusaet al. (2017) di Pantai Tongkeina Kota Manado bahwa lamun yang hidup pada substrat pecahan karang memilikipanjang akar lebih panjang dan terpendek pada substrat pasir

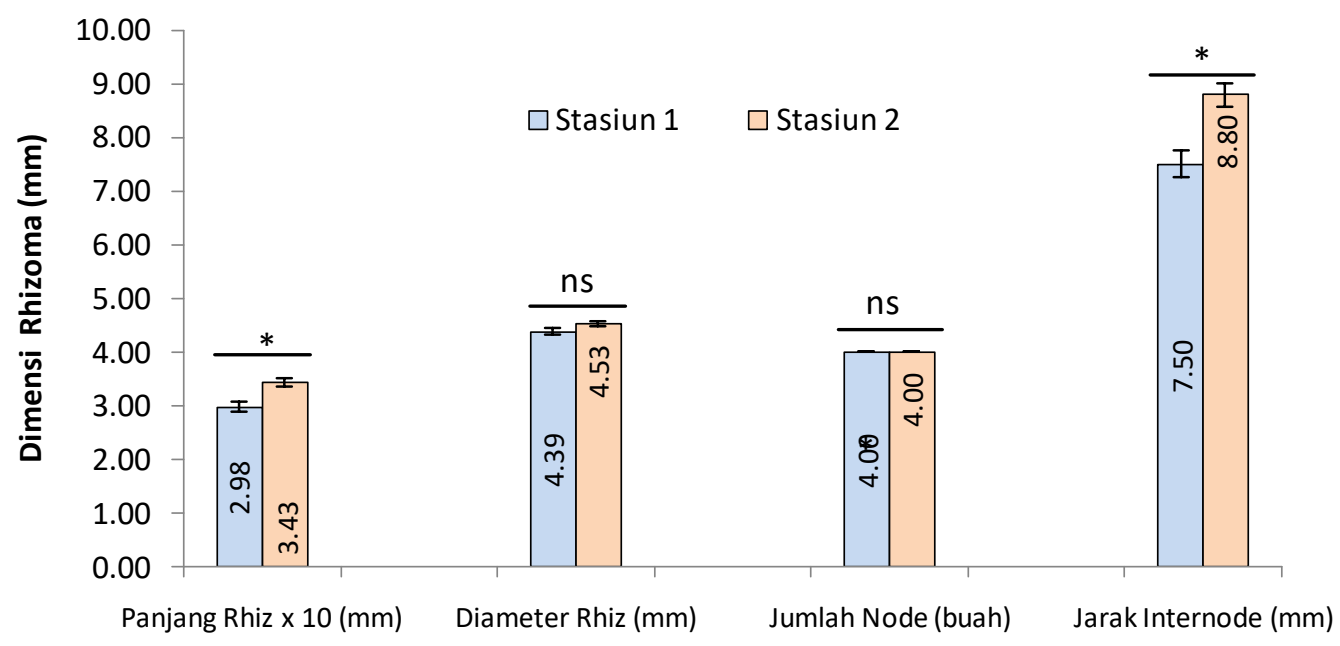

Bagian Rhizoma

Gambar 5. Karakteristik pada rhizoma lamun T. ciliatum pada kedua stasiun penelitian di Pantai Kasuso dan Pantai Panrangluhu, Kabupaten Bulukumba. (*: terdapat perbedaan yang nyata pada a 5\% berdasarkan uji t-student; ns: tidak berbeda nyata). 


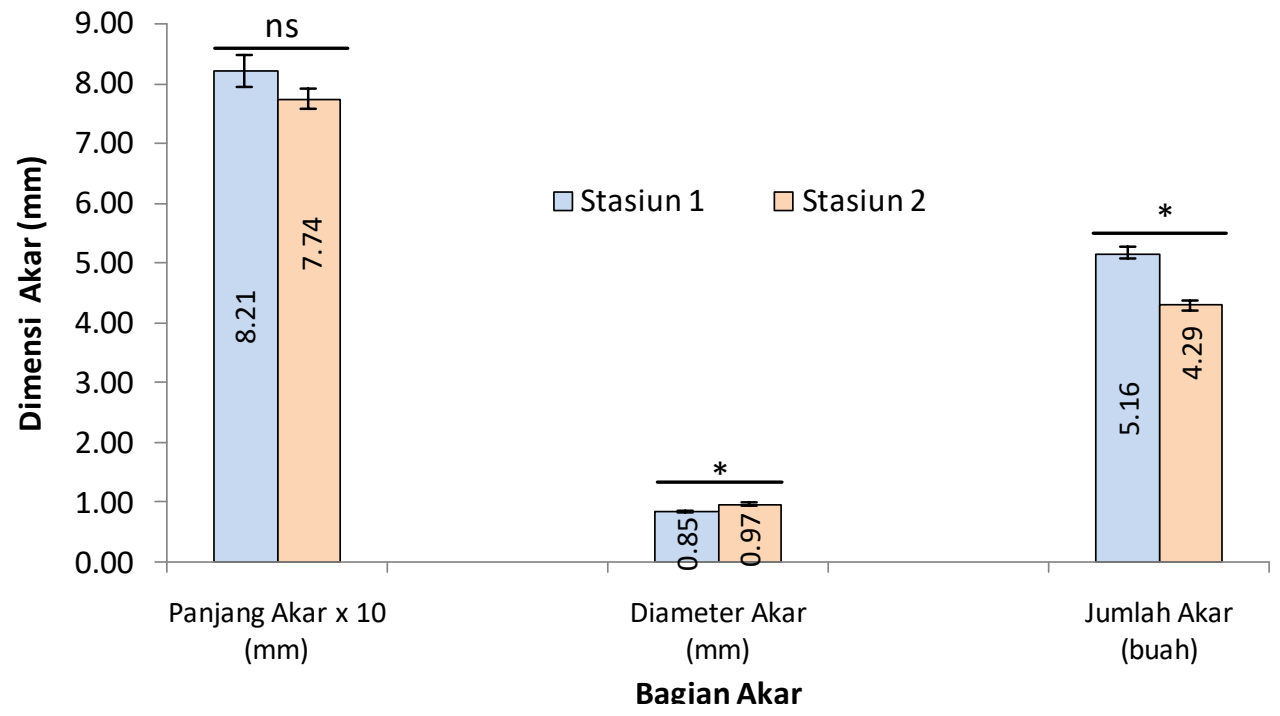

Gambar 6. Karakteristik pada akar lamun T. ciliatum pada kedua stasiun penelitian di Pantai Kasuso dan Pantai Panrangluhu, Kabupaten Bulukumba. (*: berbeda nyata pada alfa $5 \%$ berdasarkan uji t-student; ns: tidak berbeda nyata)

berlumpur. Lamun pada substrat pecahan karang memiliki ukuran butir sedimen yangkasar dan tingkat porositas yang besar dan seragam sehingga memerlukan akar yang lebih panjang untuk mencengkeram kuat substrat agar dapat bertahan dari arus dan gelombang. Namun dalam penelitian ini, didapatkan panjang akar yang relatif sama.

Meskipun panjang akar tidak
memperlihatkan namun diameter akar yang terukur di Pantai Panrangluhu lebih besar $(0,97 \mathrm{~mm})$ dan berbeda nyata dibandingkan Pantai Kasuso (Gambar 6). Faktor kekasaran substrat menjadi faktor kunci. Substrat di Pantai Panrangluhu yang memiliki ukuran butir sedimen yang sangat kasar, dan tingkat porositas yang besar dan seragam sehingga diperlukan akar yang kuat (berdiameter besar) untuk mencengkeram substrat. Lamun yang hidup di substrat yang ukuran butiran sedimen kasar atau besar cenderung memiliki perakaran yang lebih kuat dibandingkan yang hidup di substrat dengan ukuran butir sedimen lebih halus (Barko et al., 1991; Fonseca et al., 1998).

Jumlah akar yang didapatkan pada kedua lokasi penelitian memperlihatkan perbedaan yang nyata. Jumlah akar lamun di Pantai Kasuso sebesar 5,16 buah dan di Pantai Panrangluhu sebesar 4,29 buah (Gambar 6). Substrat yang lebih halus di Pantai Kasuso menyebabkan jumlah akar yang lebih banyak untuk mengikat sedimen namun ukurannya lebih pendek. Menurut Hasanuddin (2013), ukuran butiran yang lebih halus, membutuhkan jumlah akar yang lebih banyak untuk mengikat sedimen.

Variabel lingkungan yang diukur pada kedua lokasi, yaitu suhu, salinitas, kecepatan arus, kedalaman, gelombang, nitrat dan fosfat. Hasil rata-rata pengukuran variabel lingkungan disajikan pada Tabel 1 dan kandungan nutrient disajikan pada Tabel 2.

Rata-rata nilai parameter di setiap stasiun menunjukkan kisaran dan rataan yang relatif sama, kecuali kecepatan arus yang lebih tinggi di Stasiun Panrangluhu (Tabel 1).

Kisaran nilai semua kondisi perairan masih dalam batas yang normal untuk kehidupan lamun. Suhu perairan yang berkisar $30-31^{\circ} \mathrm{C}$ di kedua stasiun masih dalam kondisi yang sesuai untuk pertumbuhan lamun. Kisaran suhu tersebut dapat membantu dalam respirasi lamun dan sangat mendukung dalam pertumbuhan dan perkembangan lamun. Menurut Phillips \& 
Menez (1988), lamun dapat mentolerir suhu perairan antara $26-36^{\circ} \mathrm{C}$, akan tetapi untuk melakukan fotosintesis, suhu lamun yang optimum berkisar antara $28-30^{\circ} \mathrm{C}$. Demikian pula untuk kisaran salinitas masih dapatditolerir. Lamun memiliki toleransi salinitas yang lebar (euryhaline) dengan adaptasi morfologi daun yang memiliki kutikula yang tipis sehingga daun mampu mengabsorbsi nutrien secara langsung dari kolom air (Stapel et al., 996). Kisaran kedalaman tempat lamun ditemukan merupakan perairan yang tergolong dangkal. Perbedaan kedalaman disebabkan karena adanya perbedaan topologi dasar perairan baik pada daerah intertidal maupun subtidal. Kedalaman suatu perairan sangat erat hubungannya dengan penetrasi cahaya matahari ke dalam kolom air yang digunakan oleh tumbuhan berklorofil untuk berfotosintesis.

Kecepatan arus yang didapatkan pada Stasiun Pantai Kauso berkisar 0,03-0,04 $\mathrm{m} /$ detik dan Stasiun 2 Pantai Panrangluhu berkisar 0,07-0,11 m/detik. Kecepatan arus pada Stasiun Pantai Panrangluhu relatif lebih cepat dibandingkan Stasiun Pantai Kasuso. Keterbukaan perairan di pantai Panrangluhu menjadi alasan tingginya kecepatan arus, dibandingkan dengan Pantai kasuso yang lebih terlindung. Secara keseluruhan stasiun

Tabel 1. Rata-rata nilai parameter kualitas lingkungan di perairan Pantai Kasuso dan Pantai Panranglyhu, Kabupaten Bulukumba

\begin{tabular}{llcc}
\hline \multirow{2}{*}{ Variabel } & Statistik & \multicolumn{2}{c}{ Stasiun } \\
\cline { 3 - 4 } Suhu $\left({ }^{\circ} \mathrm{C}\right)$ & Kisaran & $30-31$ & Panrangluhu \\
Salinitas (O/OO) & Rataan & 30,4 & $30-31$ \\
& Kisaran & $33-34$ & 30,7 \\
Kedalaman (cm) & Rataan & 33,7 & $33-34$ \\
& Kisaran & $144-180$ & 33,3 \\
Kecepatan Arus (m/det) & Rataan & 163 & $99-214$ \\
& Kisaran & $0,03-0,04$ & 157,7 \\
Tinggi Gelombang (HI/3) (cm) & Rataan & 0,039 & $0,07-0,17$ \\
& Kisaran & $3-6$ & 0,107 \\
& Rataan & 3,61 & $2-6$ \\
\hline
\end{tabular}

Tabel 2. Rata-rata nilai kandungan nitrat dan fosfat pada kolom air dan sedimen di perairan Pantai Kasuso dan Pantai Panranglyhu, Kabupaten Bulukumba

\begin{tabular}{llcc}
\hline \multirow{2}{*}{ Parameter } & \multicolumn{1}{c}{ Statistik } & \multicolumn{2}{c}{ Stasiun } \\
\cline { 3 - 4 } NO3 - Air (mG/L) & Kisaran & $0,024-0,117$ & Panrangluhu \\
\hline \multirow{2}{*}{ PO4-Air (mG/L) } & Rataan & 0,047 & $0,016-0,075$ \\
& Kisaran & $0,010-0,019$ & 0,041 \\
NO3 Sedimen (mG/L) & Rataan & 0,013 & $0,010-0,015$ \\
& Kisaran & $0,590-1,260$ & 0,012 \\
PO4 Sedimen (mG/L) & Rataan & 0,849 & $0,460-2,240$ \\
& Kisaran & $5,110-9,490$ & 1,082 \\
& Rataan & 7,083 & $1,670-6,370$ \\
\hline
\end{tabular}


penelitian termasuk dalam perairan dengan kecepatan arus berkategori lambat (Mason, 1981). Arus dengan kecepatan $0,5 \mathrm{~m} /$ detik mampu mendukung pertumbuhan lamun dengan baik. Arus juga sangat penting untuk membersihkan endapan atau partikel partikel pasir yang menempel pada lamun.

Tinggi gelombang perairan yang didapatkan di kedua stasiun relatif sama. Gelombang sangat berpengaruh pada komunitas lamun yang tumbuh di daerah perairan yang dangkal. Sedangkan saat musim gelombang/ombak yang besar, kebanyakan daun lamun akan gugur, terlepas dari batang atau rhizomanya (Shortdan Coles, 2003).

Untuk kandungan nutrien pada kolom air juga menunjukkan nilai yang relatif sama antar kedua stasiun. Kisaran nilai kandungan nitrat sebesar 0,016-0,117 mG/L tergolong perairan oligotrofik dan mesotrofik, karena nilainya masih di bawah 0,29 $\mathrm{mG} / \mathrm{L}$ (Hakanson \& Brhyn, 2008). Perbedaan kandungan hara terlihat pada kandungan sedimen, yaitu rata-rata kandungan nitrat di Stasiun Panrangluhu lebih tinggi (1,082 mG/L) dibandingkan Stasiun Pantai Kasuso $(0,849$ $\mathrm{mG} / \mathrm{L})$. Namun sebaliknya kandungan Fosfat di Stasiun Pantai Kasuso lebih tinggi 7,083 $\mathrm{mG} / \mathrm{L}$ ) dibanding Stasiun Pantai Panrangluhu $(4,228 \mathrm{mG} / \mathrm{L})$ (Tabel 2). Keterkaitan antara kondisi lingkungan dan karakteristik lamun $T$. ciliatum disajikan dalam bentuk garfik dua
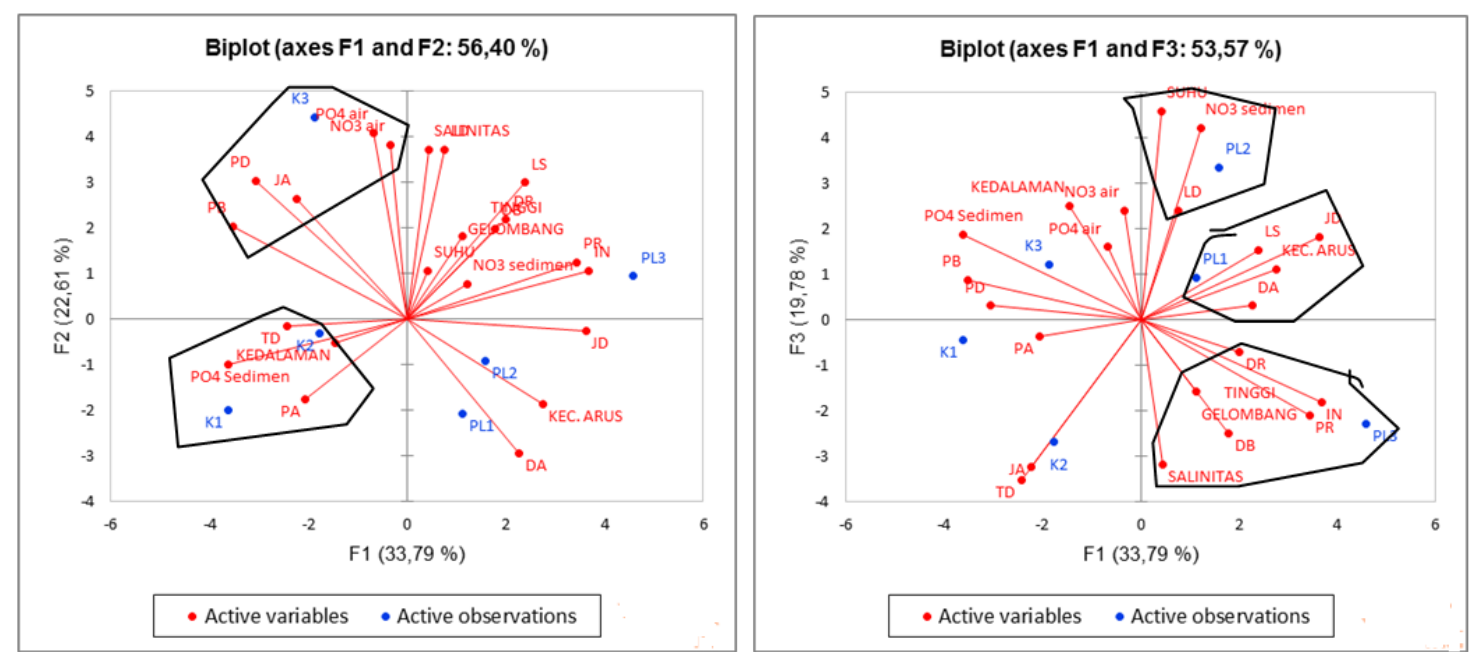

Gambar 7. Analisis Principal Component Analysis (PCA) keterkaitan faktor lingkungan dengan dimensi, hasil dari analisis PCA yang menggambarkan sebaran dari 6 substasiun berdasarkan karakter dari lingkungan dan morfometrik lamun (Gambar 7).

Teridentifikasi 5 kelompok sebaran substasiun berdasarkan karakter lingkungan dan morfometrik lamun. Kelompok 1, yang terdiri dari Substasiun K-1 dan K-2 yang berada di Stasiun Kasuso, dicirikan dengan daun yang tebal, akar yang panjang, dan terkait dengan gelombang yang rendah. Kelompok II, beranggotakan Substasiun K-3 (Pantai Kasuso), dicirikan oleh panjang daun dan batang yang lebih besar, serta jumlah akar yang lebih banyak. Karakter tersebut terkait dengan kandungan fosfat dan nitrat air yang tinggi dan arus yang lemah. Kelompok III, hanya terdiri dari substasiun PL-1 yang berada di Stasiun Panrangluhu, dicirikan dengan jumlah dan luasan daun serta diameter akar yang besar yang terkait dengan kecepatan arus yang kuat. Kelompok IV, hanya terdiri dari substasiun PL-2 yang berada di Stasiun Panrangluhu, dicirikan oleh lebar daun yang besar dan terkait yang tinggi. Sedangkan Kelompok $\mathrm{V}$, hanya Panrangluhu), dicirikan oleh diameter batang yang besar, panjang dan diameter rhizoma yang besar, serta jarak internode yang lebih lebar. Karakter tersebut terkait dengan salinitas dan gelombang yang lebih tinggi (Gambar 7). dengan suhu dan kandungan nitrat sedimen berasal dari substasiun PL-3 (Stasiun Pantai

\footnotetext{
Gambar 7. Analisis Principal
morfologi lamun
} 


\section{KESIMPULAN}

Lokasi Pantai Kasuso dengan substrat berpasir dan terlindung memiliki karakter daun yang lebih panjang dan tebal, serta akar yang lebih panjang dengan jumlah akar yang lebih banyak, sedangkan di Pantai Panranglunu dengan substrat pasir yang didominasi oleh pecahan karang memperlihatkan jumlah daun, panjang rhizoma, jarak internode, dan diameter akar yang lebih besar. Pada kondisi arus yang lemah dengan kandungan nitrat dan fosfat yang tinggi, lamun T. ciliatum, dicirikan oleh panjang batang dan daun yang lebih besar dengan jumlah akar yang banyak. Sedangkan pada arus yang kuat, lamun dicirikan oleh jumlah dan luasan daun serta diameter akar yang lebih besar. Daerah dengan gelombang yang tinggi, dicirikan oleh lamun yang memiliki diameter batang yang lebih besar, rhizoma yang lebih panjang dengan diameter yang besar, dan jarak internode yang juga lebih panjang.

\section{DAFTAR PUSTAKA}

Abal, E.G., Loneragan, N., Bowen,P., Perry, J.,Udy, J.W.\& Dennison, W.C. 1994. Physiological and morphological responses of the seagrass Zostera capricorni Aschers, to light intensity. Journal of Experimental Marine Biology and Ecology, 178(1):113-129. doi :10.1016/0022-0981 (94)90228-3

Amale, D., Kondoy, K.I., \& Rondonuwu,A.B. 2016. Struktur Morfometrik Lamun Halophila ovalis di Perairan Pantai Tongkaina Kecamatan Bunaken Kota Manado dan Pantai Mokupa Kecamatan Tombariri, Kabupaten Minahasa. Jurnal IImiah Platax, 4(2):6775.

APHA. 2017. Standrad Methods for the Examination of Water and Wastewater. $23^{\text {rd }}$ edition. American Public Health Association. 8001 Street, NW. Washington DC, 20001-3710.

Barko, J.W., Gunnison, D.,\& Carpenter, S.R. 1991. Sediment interaction with submersed macrophyte growth and community dynamics. Aquatic botany, 41 (1-3): 41-65. doi: 10.1016/0304-3770(91) 90038-7
Barnabas, A.D. \& Naidoo,Y. 1980. Ultrastructure features of the leaves of Thalassodendron ciliatum (Frossk.) den Hartog. ProceedingElectron Microscopy in Southern Africa. 10:45-46.

Barnabas, A.D. 1982. Fine structure of the leaf epidermis of Thalassodendron ciliatum (Forsk.) den Hartog. Aquatic Botany., 12:412-415

Barnabas, A.D. 1983. Composition and fme structural features of longitudinal veins in leaves of Thalassodendron ciliatum. South African Journal of Botany, 2(4): 317325

Browne, C.M., Milne, R., Griffiths, C., Bolton, J.J.\& Anderson, R.J. 2013. Epiphytic seaweeds and invertebrates associated with South African populations of the rocky shore seagrass Thalassodendron leptocaulea hidden wealth of biodiversity. African Journal of Marine Science, 35(4): 523-531. doi : 10.2989/181 $4232 X .2013 .864332$

Caboco, S., Machas, R.\& Santos, R. 2009. Individual and Population Plasticity of the seagrass Zostera noltii along a Vertical Intertidal Gradient. Estuarine, Coastal and Shelf Science, 82(2):301-308.

Collier, C. 2013. Illustration of the morphology of Thalassodendron ciliatum. Integration and Application Network, Center for Environmental Science, University of Maryland. Maryland USA.

De Silva, K.H.W.L. \& Amarasinghe, M.D., 2007. Substrate characteristics and species diversity of marine angiosperms in a micro-tidal basin estuary on west coast of Sri Lanka. Sri Lanka Journal Aquatic Sciences. 12:103 114. doi : 10.4038/sljas. v12i0.2217.

Ducker, S.C., Pettitt, J.M., \& Knox, R.B.. 1978. Biology of Australian seagrasses: Pollen development and submarine pollination in Amphibolis antarctica and Thalassodendron ciliatum (Cymodoceaceae). Australian Journal of Botany, 26(3):265-285. doi :10.1071/BT9 780265

Duarte, M.C., Bandeira, S. \& Romeiras, M.M. 2012. Systematics and Ecology of a New Species of Seagrass (Thalassodendron, Cymodoceaceae) from Southeast African Coasts. Journal for Botanical 
Nomenclature, 22(1):16-24. doi :10.3417/ 2010079

Fonseca, M.S., KenworthyW.J. \& Thayer, G.W. 1998. Guidelines for the conservation and restoration of seagrasses in the United States and adjacent waters, Silver Spring (MD) National Oceanic and Atmospheric Administration (NOAA) Coastal Ocean Office, NOAA Coastal Ocean Program Decision Analysis Series no. 12.

Hakanson, L.\& Brhyn, A.C.2008.Eutrophication intheBalticSeaPresentSituation, Nutrien Transport Processes, Remedial Strategies. Springer-Verlag Berlin Heidelberg

Kay, Q.O.N. 2008. Floral structure in the marine angiosperms Cymodocea serrulata and Thalassodendron ciliatum (Cymodocea ciliata).Botanical Journal of the Linnean Society, 64(4): 423-429. doi : $10.1111 /$ j.1095-8339.1971.tb02155.x

Kiswara, W. 1992. Vegetasi lamun (seagrass) di rataan terumbu Pulau Pari, PulauPulau Seribu Jakarta. Oseanologi di Indonesia, 25:31-49.

Kiswara, W. \& Azkab, M.H. 2000. Spesismen Lamun (Seagrass) yang Tersimpan di dalam Koleksi Referensi Puslitbang Oseanologi-LIPI, Jakarta.Pusat Penelitian dan Pengembangan OseanologiLembaga IImu Pengetahuan Indonesia. Jakarta.

Kiswara, W. 1996. Inventory of Seagrass in Kuta and Gerupuk Bays, Lombok Indonesia. Seagrass Biology : Proceedings of an international workshop Rotness Island Western Australia 25-29 January 2006. pp 27-32.

Marba, U. \& Duarte, C.M. 1998. Rhizome elongation and seagrass clonal growth. Mar. Ecol. Prog. Ser., 174(1 1):269-280.

Mashoreng, S., Rahman, R., Rahman, N.A.,\&Rahman, F.N .2019a. Serapan Karbon Lamun Thalassodendron ciliatum di Perairan Panrangluhu Kabupaten Bulukumba Propinsi Sulawesi Selatan. Prosiding Simposium Nasional Kelautan dan Perikanan VI, Universitas Hasanuddin, Makassar, 21 Juni 2019.

Mashoreng, S., Alprianti, S., Samadi, W., Isyrini, R. \& Inaku, D.F. 2019b. Serapan Karbon Lamun Thalassia Hemprichii Pada Beberapa Kedalaman. Spermonde: Jurnal Ilmu Kelautan, 5(1):11-17. doi : 10.20956/jiks.v5i1.7031
McDonalds, A., Prado, P., Heck, K., Fourqurean, J.W., Frankovich, T., Dunton, K.H. \& Cebrian, J. 2016. Seagrass growth, reproductive, and morphological plasticity across environmental gradients over a large spatial scale. Aquatic Botany, 134:87-96. doi : 10.1016/j.aqua bot.2016.07.007

Phillips, R.C. \& Menez, E.G. 1988. Seagrass. Smithsonian Institution Press, Washington, D.C.

Pranata, A., Suwastika, I.N. \& Paserang, A.P. 2018. Jenis - jenis Lamun (Seagrass) di Kecamatan Tinangkung, Banggai Kepulauan, Sulawesi Tengah. Natural Science: Journal of Science and Technology, 7(3):349-357.

Priosambodo, D. 2007. Sebaran Jenis-Jenis Lamun Di Sulawesi Selatan.Jurnal Bionature, 8(1): 8-17.

Putri, I.A.R.M., Dirgayusa, I.G.N.P.,\& Faiqoh, E. 2018. Perbandingan Morfometrik dan Meristik Lamun Halophila ovalis di Perairan Pulau Serangan dan Tanjung Benoa, Bali. Journal of Marine and Aquatic Sciences, 4(2):213-224.

Sahertian, D.E. \& D. Wakano. 2017. Laju Pertumbuhan Daun Enhalus Acoroides Pada Substrat Berbeda Di Perairan Pantai Desa Poka Pulau Ambon. Jurnal Biology Science \& Education, 6(1):62-68

Sakey, W.F., Wagey, B.T.,\&Gerung G.S. 2015. Variasi Morfometrik Pada Beberapa Lamun di Perairan Semenanjung Minahasa. Jurnal Pesisir dan Laut, 1 (1):1-7.

Short, F.T. \& Coles, R.G. 2003. Global Seagrass Research Methods. Elsevier Science. Netherlands.

Sjafrie, N.D.M., Hernawan, U.E., Prayudha, B., Supriyadi, I.H., Iswari, M.Y., Rahmat, K. Anggraini, Rahmawati, S., \& Suyarso. 2018. Status padang lamun Indonesia 2018. Ver. 02. Coremap-CTI - Pusat Penelitian Oseanografi LIPI. Jakarta.

Stapel, J. Aarts, T.L., van Duynhoven, B.H.M., de Groot, J.D., van den Hoogen, P.J.W. \& Hemminga, M.A. 1996. Nutrient uptake by leaves and roots of the seagrass Thalassia hemprichii in the Spermonde Archipelago, Indonesia. Marine Ecology Progress Series., 134(4):195-206

Supriharyono. 2007. Konservasi Ekosistem Sumber Daya Hayati. (1stEd.) Yogyakarta, Indonesia. Pustaka Pelajar 
Verheii, E. 1993. Marine Plants On The Reefs of The Spermonde Archipelago, SW Sulawesi, Indonesia : Aspect of Taxonomy, Floristics and Ecology. Rijks herbarium/Hortus Botanicus. Leiden. 320 $\mathrm{pp}$.

Wagey, B.T. 2013. Morphometric Analisis of Seagrass Species In Negros Oriental. Jurnal IImiah Sains, 13(2):93-97

Wangkanusa, M.S., Kondoy, K.I.F., \& Rondonuwu, A.B. 2017. Identifikasi
Kerapatan dan Karakter Morfometrik Lamun Enhalus acoroides Pada Substrat yang Berbeda Di Pantai Tongkeina Kota Manado. Jurnal IImiah Platax, 5(2):210220

Yunitha, A., Wardianto, Y. \& Yulianda, F. 2014. Diameter Substrat dan Jenis Lamun di Pesisir Bahoi Minahasa Utara: Sebuah Analisis Korelasi. Jurnal IImu Pertanian Indonesia, 19(3):130-135. 